\author{
Iskra Petkova \\ ORCID: 0000-0001-5736-4006 \\ Uniwersytet Medyczny w Plewen \\ Bułgaria
}

\title{
'Formation of skills for independent life' a training program for students preparing them to work with children at risk
}

\author{
'Формирование навыков для независимой жизни' \\ - программа обучения студентов работе \\ с детьми группы риска
}

https://doi.org/10.34739/sn.2019.19.06

\begin{abstract}
A training program, 'Formation of skills for independent life while working with children at risk' is presented in the paper. It is intended for students of Social Activities, a field of study. Objectives and tasks are defined in the articles, and the basic knowledge and skills that students receive during the process of training under this program are specified. The content of the program is presented in two parts. Part one covers methodological principles applied in formation of skills for independent life. Three main stages to be mastered by the students in the training process within the stage of forming skills for independent life in children from risk groups are elaborated. Part two of the program covers five sections for mastering individual and group techniques of a practical and applied nature; its content is included in Trainer's Manual.
\end{abstract}

Keywords: students, training, children, skills, independent living

Резюме: Представлена разработанная учебная программа «Формирование навыков для независимой жизни при работе с детьми группы риска» при обучении студентов специальности «Социальные деятельности». Сформулированы цели и задачи, определены основные знания и умения, которые студенты получают в процессе обучения Программе. Содержательная сторона Программы представлена в двух частях. В первой части рассмотрены методологические принципы при формировании навыков для независимой жизни. Прокомментированы три основных этапа усвоения в процессе обучения студентов циклу формирования навыков для независимой жизни детей группы риска. Вторая часть Программы включает в себя пять направлений усвоения индивидуальных и групповых техник практико-прикладного характера, содержательная часть которых заложена в Указаниях для обучающих.

Ключевые слова: студенты, обучение, дети, навыки, самостоятельная жизнь 


\section{Introduction}

Objective expectations toward Republic of Bulgaria as a full member of the EU have been related to that the state shall be a specific guarantor for the future of its citizens and stability of united Europe. The focus is on formation of certain qualities in individuals that allow for flexibility and adaptivity to new economic and social realms. Such adaptation is extremely difficult for one of the most vulnerable groups - the children, because they need a strategy for protection, social security and support for a successful social realization. Social work with children from vulnerable groups requires professional training, adequate to dynamic social changes, for improved quality of care. The social worker needs knowledge and skills relevant to individual needs of various groups of children in risk.

The issue related to the necessity to form skills for autonomous and independent life in these children is substantiated through the social reality:

- Ineffective connection and support from family environment, especially for these who use institutional social care or alternative care (centres of family type), or some features and negative influence by the family environment (low culture and low living standard of parents);

- Specifics in children's health condition and social status that lead to problems in their social support and protection, thus constraining their successful re-integration and socialization;

- Low awareness of social, health and educational services in the community.

The social worker working with these groups of children stands in front of the challenge to be well informed about practically oriented educational programs and approaches, that not only provide information (knowledge) to children, but form, to a higher extent, skills for adequate behavior in various circumstances, skills to test behavioral models for coping with moral dilemma and difficulties with multi-choice options.

Issues related to risk behavior prevention shall be addressed through health, social and educational policies for inter-sectoral cooperation applied in synchrony. Good combination between education that creates skills and quality educational, health and social services guarantees restriction of risky behavior and of factors for vulnerability in children [Popova, 2007, s. 8]. 
All these provide grounds for the development of academic training program for formation of skills for independent life, for working with children in risk, for the training of students studying Social Activities.

Main objective of the Program "Formation of skills for independent life for working with children at risk" is mastering the specifics of work with set of complex skills, by the students, to improve the quality of life of children from vulnerable (risk) groups.

\section{Specific objectives:}

1. Mastering the specifics and scope of issues in various risk groups of children.

2. Introducing and learning a methodology for formation of skills for independent life.

3. Mastering individual and group techniques for practical work in formation of skills for independent life and for improved quality of life of children from vulnerable groups.

Main knowledge and skills that will be provided to students in the training process:

- In the course of training the main aspects of mechanisms of formation of skills for independent life and improved quality of life of children from vulnerable (risk) groups are mastered;

- Knowledge and skills of theoretical and practically applied nature are mastered. Obtained knowledge and learned skills are applied by the social workers in the work with children in need of special support for independent life.

- Volume and nature of suggested material are in line with the specific tasks and professional competence of the social worker. Practical sessions are focused on development of models of interaction, techniques for joint work with typology of various groups of children with social issues, and mediation of the social worker among other factors for socialization of individuals.

In the first part of the program methodological principles for formation of skills for independent life are exposed. The purpose is to equip students with skills for their work and support to children in risk; by using relevant methods, to be able to provide necessary information to the children, so they can take initiative and start bearing responsibility for their own lives. The training cycle for formation of skills for independent life of children from risk groups is mastered, and it contains three main stages: 
- Definition of skill nature: through examples, constant encouragement for repetitive use of the skill - verbally or through action, corrective actions in case of incorrect understanding or use;

- Formation of basic and most significant skills through created conditions for their practical use under trainer supervision, and effective feedback, assessment of achieved goals, and also recommendations in case of incorrect use of skills;

- Creation of conditions for permanent mastering of skills through providing options for sharing own experience, stimulation of selfassessment and behavioral change in the right direction [Popova, 2007, s.15-16].

During their training under the program, the students master skills for selection of contents for practical training modules by:

- assessing the actual level of skills of each child;

- considering age and individual specifics, presence of life experience and stage of developed cognitive processes in each child;

- taking into account the level of satisfied specific needs and necessities of the child in unequal social position through guaranteed protection of child's personal dignity and observed moral norms in relations with the people who take care of the child;

- assessing the options to provide support to children in the process of mastering methods for independent problem-solving, pro-activity and emotionally-cognitive attitude towards the activity;

- Determining the options for personal expression of each child, and at the same time observing the equality right of each child in the process of pedagogical interaction.

The second part of the program covers five sections for mastering individual and group techniques of practical and application nature; its content is included in editions of Trainer's Manual - "Formation of skills for independent life" [Popova, 2007], "Formation of skills for independent life for children from 3 to 7" [Petkova, Bratanova, Rosmanowa, Ivanova, 2012], "Guide training and clinical practice in the occupational therapy" [Vacheva, 2015] and "Guide training and clinical practice in the ergotherapy" [Vacheva, 2017], used by the students as practical manuals. Each Section contains a few units (modules), with clearly formulated objectives: 
- Section "Everyday skills for life" includes the modules "Nutrition", "Hygiene", "Healthcare", "Suitable clothing and care for clothes", "How to manage our finances"

- Section "Skills for life related to housing and local services". Modules: "Let's get to know the city and its surroundings"; "Living in independent home"; "How to ask public institutions for assistance and how to use public services". Modules for younger children are formulated as "The city we live in", "The home we live in", "The school we study at";

- Section "Social and personal skills for life", with modules: "Selfknowledge", "My family", "Control on emotions and conflict prevention" , "Communication";

- Section "Sexual and reproductive health", with the following modules: "The human body", "Healthcare", "The changes in my body. Reproductive system in humans", "Getting pregnant and pregnancy", "Human sexuality" , "Contraceptive methods", "Prevention of STD", "Prevention of HIV/AIDS", "Responsible sexual behavior", "Prevention of substance abuse";

- Section "Free time management", modules: "What can I do during my free time?" ("Daily routine"), "Time management skills", "Learning skills".

The practical manuals provide developed model exercises. The purpose is not only to train the students in the technology to apply the extensive set of methods and means in order to implement the objectives of the training, but to provoke their creative thinking, to stimulate using, testing and experimenting with different models of work in their future professional experience.

\section{Conclusion}

By completing the theory and practical training under the program "Formation of skills for independent life for working with children at risk", the students studying Social Activities master the following professional skills:

- To identify needs for learning skills for independent life in children from risk groups;

- To master techniques for practical work for acquiring skills for independent life, for working with children from various vulnerable groups;

- To master skills for individual approach in every single case; 
- To form skills for joint work with the families of the children, that need a special support for an independent life;

- To master practical skills for development of individual plan for formation of skills for independent life, for a concrete case of a child from risk group.

\section{Literature}

Petkova I., Bratanova G., Rosmanova I., Ivanova K., (2012), Trainer's Manual. Formation of skills for independent life for children from 3 to 7, Faber, Veliko Tarnovo. [In Bulgarian]

Trainer's Manual. Formation of skills for independent life, compiled by Julia Popova, (2007), Smart IA EOOD. [In Bulgarian]

Vacheva D., (2015), Guide training and clinical practice in the occupational therapy. ENS-PRESS, Gabrovo. [In Bulgarian]

Vacheva D., (2017), Guide training and clinical practice in the ergotherapy, University Press Medical University, Pleven. [In Bulgarian] 